\title{
Multiple Logic Functions Based on Small Molecular Fluorene Derivatives and Their Application in Cell Imaging
}

\author{
Jing Guo, ${ }^{\dagger, \dagger}$ Liangliang Han, ${ }^{\dagger}$ Xichang Bao, ${ }^{\dagger}$ Zhengkun Du, ${ }^{\dagger}$ Ting Wang, ${ }^{\dagger}$ and Renqiang Yang $*^{\dagger}$ \\ ${ }^{\dagger}$ CAS Key Laboratory of Bio-based Materials, Qingdao Institute of Bioenergy and Bioprocess Technology, Chinese Academy of \\ Sciences, 189 Songling Rd., Qingdao 266101, China \\ ${ }^{*}$ University of Chinese Academy of Sciences, Beijing 100049, China
}

Supporting Information

ABSTRACT: Multiple logic functions including dual-input dual-output NOR and AND gates, dual-input dual-output NOT and AND gates, and a three-input NOR gate are fabricated with fluorene-based small molecule/DNA probes (named FSM/DNA probes), which sequences are well-designed. The FSM/DNA probes can be quenched by dsDNA, aptamer-target complex and free dyes (SG I and EB) without the attachment of additional quencher moiety. The quencher-free FSM/DNA probe also presents a way for detection of ATP. In addition, the feasibility of a $\mathrm{pH}$-induced "ON-OFF" fluorescence switching system is demonstrated through the carboxylic acid-terminated fluorene derivatives $\left(\mathrm{F}(\mathrm{COOH})_{2}\right.$ and $\mathrm{FSM} / \mathrm{DNA}$ probe $)$ by taking advantage of protonation/deprotonation process occurring at the carboxylic acid functional groups. The formation of deprotonated $\mathrm{F}\left(\mathrm{COO}^{-}\right)_{2}$ emits fluorescent ("ON" state) at neutral and alkaline $\mathrm{pH}$ ranges, whereas the $\mathrm{F}(\mathrm{COOH})_{2}$ with the protonated carboxylic acid groups quenches the emission of fluorene ("OFF" state) at acidic $\mathrm{pH}$ ranges. Switching function based on the FSM/DNA probe can

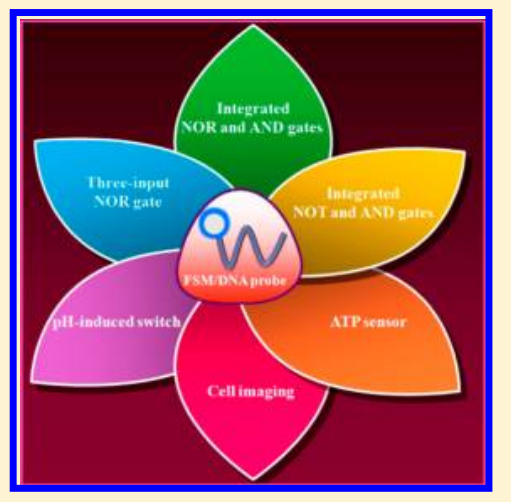
be performed in totally aqueous solution. Interestingly, the FSM/DNA probe exhibits high fluorescence brightness, biocompatibility, cell membrane penetrability, and thus it has been applied in live cell imaging investigation.

\section{INTRODUCTION}

Since the original conception of "molecular logic gate" introduced by de Silva, ${ }^{1}$ this field experienced a boost in popularity. Various molecules, enzyme, and peptide have been used as active components in such biocomputational systems. $^{2-5}$ In particular, the use of DNA as an ideal candidate for molecular programming and information processing shows great promise in the fields of biocomputing, bioanalysis, and nanomachines. $^{6-11}$ The behavior of DNA molecules with particular sequences can be reliably predicted according to the Watson-Crick base pairing principle. ${ }^{12}$ In addition, some structural and functional properties of DNA have been exploited to design logic gates, which are based on nonWatson-Crick base pairing principle. For example, structured DNA such as G-quadruplexes, i-motifs, molecular beacon, and left-handed Z-DNA has been employed to perform logic functions based on conformational conversion or structural transition, which responds to the input signals such as metal ions, $\mathrm{pH}$, complementary DNA (DNAc), and carbon dots. ${ }^{13-17}$ Logic gates with functional DNA, such as DNAzymes, which are DNA molecules possessing catalytic activity, and nucleic acid aptamers can be stimulated by the recognition with target biomolecules. ${ }^{13,18-21}$ Thus, based on the fact that changes in the DNA structure by input signals is always accompanied by physical or chemical changes, various DNA-based logic gates, switches and tweezers have been built and investigated in recent years. ${ }^{22}$ However, the construction of complex systems with multiple logic functions that respond to external stimuli remains a challenge and makes computing difficult. To overcome these problems, integrated molecular devices can offer a potential avenue to improve the computational power and functionality of DNA logic gates. ${ }^{12,23-25}$

Fluorene-based materials have obtained great attraction as the active materials in organic optoelectronic devices, such as organic light emitting diodes, ${ }^{26,27}$ organic photovoltaic cells, ${ }^{28-30}$ and electrophosphorescent devices. ${ }^{31,32}$ In addition, owing to the excellent photostability, high fluorescence brightness, and easy modification, fluorene and its derivatives have recently found applications in sensors ${ }^{33-39}$ and construction of molecular machines. ${ }^{2,40,41}$ For example, Wang and coauthors have reported multiple logic gates based on the electrostatic interaction between cationic polyfluorene and negatively charged Y-DNA, respectively, labeled at the $5^{\prime}$ termini with fluorescein that realized the multiplex detection of nucleases. ${ }^{41}$ In this system, fluorescence resonance energy transfer (FRET) provides an effective approach for investigating the changes in fluorescence intensity occurring between the donor and the acceptor. Actually, FRET as a commonly used technique presents a valuable method for developing multiple optical-logic gates. ${ }^{42,43}$ The FRET-based DNA logic functions mainly rely on the changes in the DNA structure in response to

Received: February 19, 2014

Revised: April 16, 2014

Published: April 17, 2014 
external stimuli, which result in the fluctuation of fluorescence intensity of the dyes.

The optical and electronic properties of fluorene-based materials highly depend on their chemical structures. ${ }^{36,44,45}$ As described previously, the molecular backbone of polyfluorene has a large number of absorbing units with efficient intrachain and interchain energy-transfer channels to amplify fluorescence sensing signals. In addition, cationic polyfluorene can form a complex with oppositely charged biomolecules through strong electrostatic interactions. ${ }^{41,46}$ Therefore, these kinds of polyfluorenes can be used as a sensitive optical platform for the construction of multiple DNA logic gates with the ability of simultaneous detection of multiplex targets, which will improve the development of logic gates in computing and the intelligently sensing due to their signal amplification based on FRET. Although there are plenty of studies on the polyfluorene-based logic gates and sensors, the research on small molecular fluorene-derivative-based DNA logic gates is relatively few. ${ }^{47}$ Moreover, with respect to the determination of $\mathrm{pH}$, modification at the ninth carbon position of the fluorene is a typical example of $\mathrm{pH}$ fluorescent sensors because their absorption and emission can be tuned by the photoinduced electron transfer (PET) or intramolecular charge transfer (ICT) process between its donor and acceptor parts of the fluorescent molecules. ${ }^{40,48}$ For example, Lu et al. reported a series of 9-(cycloheptatrienylidene)-fluorene derivatives used as $\mathrm{pH}$ sensing agents. ${ }^{40,49-51}$ The working principle relies on the reversible protonation and deprotonation processes taking place at the dimethylamino groups and hydroxy groups in different $\mathrm{pH}$ conditions, which enhances or inhibits the PET process between five and seven member rings. These fluorene derivatives usually incorporate aniline, phenol, and nitrogenous heterocyclic substituents used as the active end groups or attached to the terminus of side chains. ${ }^{40,48,52}$ However, the research of the effect of $\mathrm{pH}$ on carboxylic acid substituted fluorene derivatives is few reported.

It is well established that the carboxylic acid can be deprotonated at high $\mathrm{pH}$ values, and the carboxylate anion $\left(\mathrm{COO}^{-}\right)$is formed. At low $\mathrm{pH}$, carboxylic acid is protonated and exists as neutral $\mathrm{COOH} .{ }^{53-55}$ The protonation/deprotonation process will change the interaction between the fluorescent molecules and the degree of molecular aggregation in aqueous media, which reflects in the difference in ground and excited states. ${ }^{56}$ Concomitantly, their photophysical properties involving the absorption and fluorescence characteristics will be $\mathrm{pH}$-dependent. Therefore, in this work, we develop multiple logic gates and $\mathrm{pH}$ triggered switch with the fluorene-based small molecule derivatives (including $\mathrm{F}(\mathrm{COOH})_{2}$ and FSM/ DNA probes, Scheme 1). DNA intercalating chromophores, SYBR Green I (SG I) and ethidium bromide (EB), and adenosine triphosphate (ATP) have been employed as input signals to realize a set of dual-input dual-output logic gates and a three-input logic gate by observing the emission intensities of the fluorescent molecules (FSM, SG I, EB). With multiple inputs, this gate can accept and produce more information. Thus, the multiple logic gates based on FSM/DNA probes containing different sequence can serve as a basic and versatile building block for constructing more complex circuits. Additionally, the $\mathrm{pH}$-induced switching function was explored with the carboxylic acid-terminated $\mathrm{F}(\mathrm{COOH})_{2}$ and FSM/ DNA probe. The absorption and emission properties of $\mathrm{F}(\mathrm{COOH})_{2}$ have been investigated over a wide $\mathrm{pH}$ region ( $\mathrm{pH} 1-14)$. The alkaline and acidic effects on the spectral
Scheme 1. Chemical Structure of $\mathrm{F}(\mathrm{COOH})_{2}$, FS, and FSM/ DNA Probe and the Sequences of All Oligonucleotides Used in This Study

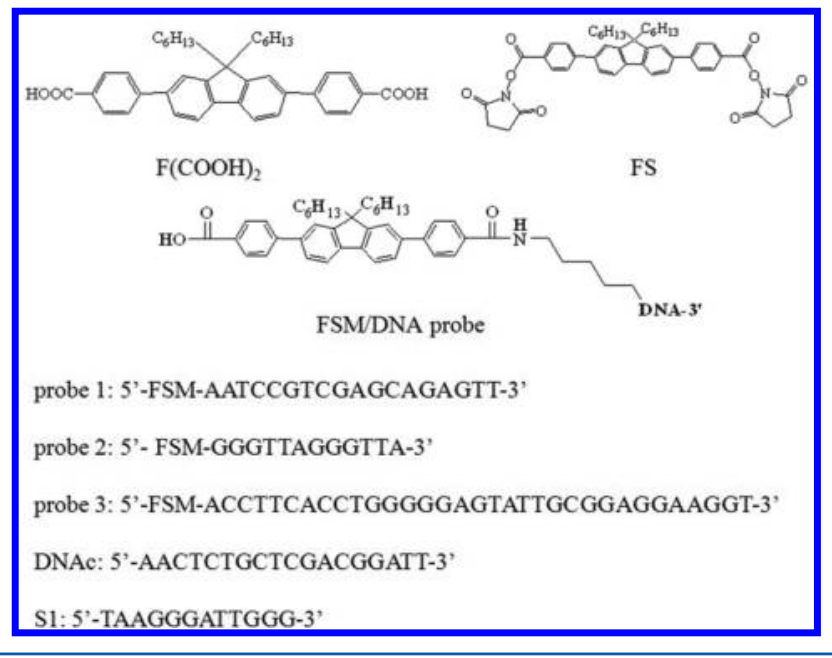

properties of $\mathrm{F}(\mathrm{COOH})_{2}$ were compared with those of carboxylic acid-free fluorene derivative FS (Scheme 1). In our work, the switching system can operate quickly and reversibly. Meanwhile, the FSM/DNA probe shows good biocompatibility and excellent cell membrane permeability, and thus, it has been successfully applied in live cell imaging investigation.

\section{EXPERIMENTAL SECTION}

Materials. All the chemical reagents were purchased from Sigma-Aldrich Chemicals Co. and used without further purification. Oligonucleotide was custom-made by TAKARA Biotechnology Co. Ltd., Dalian, China. HPLC purified FSM/ DNA probe was dissolved in water prior to use and its concentration was quantified using NanoVue spectrophotometer (GE). Milli-Q ultrapure water was used for all experiments.

Synthesis of $\mathrm{F}(\mathrm{COOH})_{2}, \mathrm{FS}$, and FSM/DNA Probes. Small molecular fluorene derivatives $\mathrm{F}(\mathrm{COOH})_{2}, \mathrm{FS}$, and the FSM/DNA probes were synthesized according to literature procedures. ${ }^{38}$ A carboxyl group at one end of the $\mathrm{F}(\mathrm{COOH})_{2}$ was covalently linked to the $5^{\prime}$ end of a ssDNA to form the FSM/DNA probe and then purified by HPLC method. The sequences of the FSM/DNA probes and other oligonucleotides used here are listed in Scheme 1.

Preparation of the Integrated NOR and AND Gates with FSM/DNA Probe 1. The small molecular fluorene derivative was covalently linked to the $5^{\prime}$ end of a ssDNA to form the FSM/DNA probe 1. As shown in Figure 1, probe 1, with a random ssDNA sequence was used as the gate strand in this program. The input signals $\left(\mathrm{I}_{1}\right.$ and $\left.\mathrm{I}_{2}\right)$ were the DNAc and SG I, respectively. The samples were prepared according to the four different input combinations of DNAc and SG I: $(0,0)$, (0, $1),(1,0)$, and $(1,1)$. Each sample was mixed in the buffer solution containing $20 \mathrm{mM}$ TrisHCl pH 7.4, $50 \mathrm{mM} \mathrm{MgCl}_{2}$, and incubated for $10 \mathrm{~min}$ at room temperature (at the final concentrations of $0.02 \mu \mathrm{M}$ for both probe 1 and DNAc) and then $5 \mu \mathrm{L}$ SG I $(400 \times)$ were added into the samples of $(0,1)$ and $(1,1)$. The outputs were determined by measuring the fluorescence intensity at 412 and $526 \mathrm{~nm}$ with excitation at 340 nm.

Preparation of the Integrated NOT and AND Gates with FSM/DNA Probe 2 . The $\mathrm{K}^{+}$specific oligonucleotide was split into $5^{\prime}$ fragment and $3^{\prime}$ fragment (S1 in Scheme 1) 


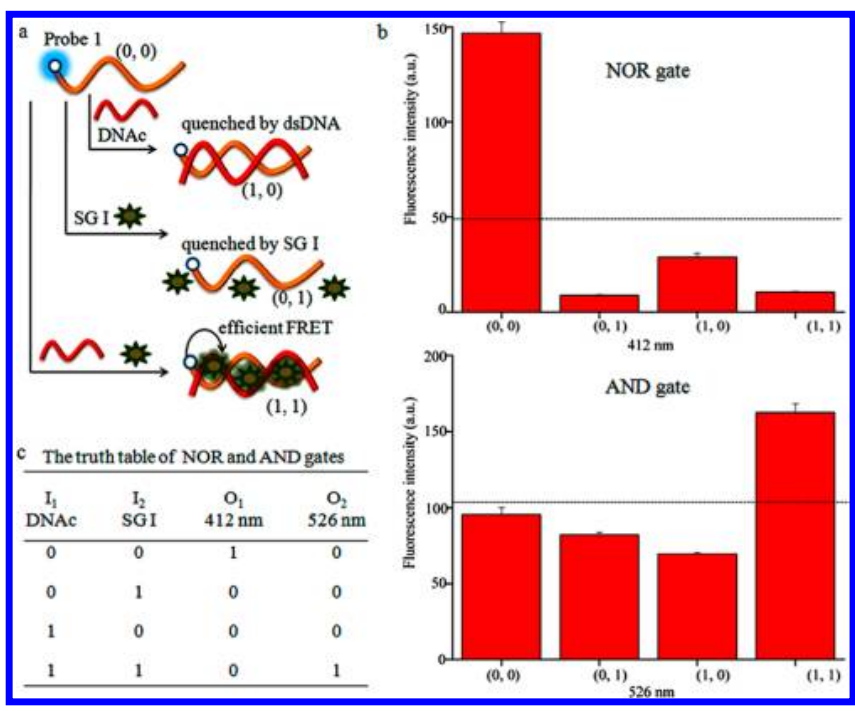

Figure 1. Integrated NOR and AND logic gates based on probe 1. (a) Schematic representation of the performing of NOR and AND gates: $\mathrm{I}_{1}$, DNAc; $\mathrm{I}_{2}$, SG I. (b) Fluorescence changes at 412 and $526 \mathrm{~nm}$ by excitation at $340 \mathrm{~nm}$. (c) Truth table of the NOR and AND gates.

without disturbing the binding activity with $\mathrm{K}^{+}$. FSM was covalently linked to the $5^{\prime}$ end of the $5^{\prime}$ fragment of $\mathrm{K}^{+}$specific oligonucleotide (probe 2 in Scheme 1). Then, the welldesigned probe 2 and $S 1$ were used as gate strands for the construction of integrated NOT and AND gates. $\mathrm{K}^{+}$and SG I were used as inputs 1 and 2, respectively. The samples were prepared according to the four different input combinations of $\mathrm{K}^{+}$and SG I: $(0,0),(0,1),(1,0)$, and $(1,1)$. Probe 2 and $S 1$ were mixed in the buffer solution containing $20 \mathrm{mM}$ TrisHCl $\mathrm{pH} 7.4,50 \mathrm{mM} \mathrm{NaCl}$, and $50 \mathrm{mM} \mathrm{KCl}$, and the final concentrations of probe 2 and $\mathrm{S} 1$ were $0.8 \mu \mathrm{M}$. The samples were incubated for $20 \mathrm{~min}$ at $37^{\circ} \mathrm{C}$ and then allowed to slowly cool to room temperature in $1 \mathrm{~h}$. After that, $5 \mu \mathrm{L}$ SG I $(400 \times)$ was added into the samples of $(0,1)$ and $(1,1)$, and they were incubated for another $5 \mathrm{~min}$ at room temperature. The outputs were determined by measuring the fluorescence intensity at 412 and $526 \mathrm{~nm}$ with excitation at $380 \mathrm{~nm}$.

Preparation of the Three-Input NOR Gate with FSM/ DNA Probe 3. The small molecular fluorene derivative was covalently linked to the $5^{\prime}$ end of ATP aptamer to form the FSM/DNA probe 3, which was used as gate strand for the construction of three-input NOR gate. ATP, SG I, and EB were used as inputs 1, 2, and 3, respectively. The samples were prepared according to the eight different input combinations of ATP, SG I, and EB: $(0,0,0),(0,0,1),(0,1,0),(0,1,1),(1,0$, $0),(1,0,1),(1,1,0),(1,1,1)$. The samples were prepared and mixed in the buffer solution containing $10 \mathrm{mM}$ TrisHCl $\mathrm{pH} 7.4$ and $50 \mathrm{mM} \mathrm{NaCl}$. The final concentrations of probe 3, ATP and $\mathrm{EB}$ were $0.02 \mu \mathrm{M}, 1 \mathrm{mM}$, and $2.5 \mu \mathrm{M}$, respectively. SG I (400X) $5 \mu \mathrm{L}$ were added into the corresponding samples. All of the samples were incubated for $5 \mathrm{~min}$ at room temperature, and the outputs were determined by measuring the fluorescence intensity at $412 \mathrm{~nm}$ with excitation at $340 \mathrm{~nm}$.

ATP Assay Protocol. All experiments for ATP assay were performed in $10 \mathrm{mM}$ TrisHCl buffer $\mathrm{pH} 7.4$ containing 100 $\mathrm{mM} \mathrm{NaCl}$ and $50 \mathrm{mM} \mathrm{MgCl}$. Stock solutions $\left(1 \times 10^{-4} \mathrm{M}\right)$ of probe 3 were prepared in ultrapure water. A total of $0.4 \mu \mathrm{L}$ of the probe 3 stock solution was diluted to $2 \mathrm{~mL}$ with buffer, and the resulting solution was incubated at room temperature for 10 min with and without ATP (the final concentration was 1.0
$\mathrm{mM})$. Then, the fluorescence spectra were measured by exciting probe 3 at $340 \mathrm{~nm}$. The same protocol was repeated in the presence of $1.0 \mathrm{mM}$ ATP analogues (AMP, CTP, GTP, and UTP, respectively) instead of ATP for the selectivity evaluation.

pH Titration. Stock solutions of $\mathrm{F}(\mathrm{COOH})_{2}\left(1.7 \times 10^{-3}\right.$ $\mathrm{M})$ and FS $\left(1.3 \times 10^{-3} \mathrm{M}\right)$ was prepared in DMSO and DMF, respectively. Then, a quantity of $0.4 \mu \mathrm{L}$ of the solution was diluted with $2 \mathrm{~mL}$ of ultrapure water with different $\mathrm{pH}$ values to obtain the experimental samples. The stock solution $\left(1 \times 10^{-4}\right.$ $\mathrm{M})$ of FSM/DNA probe 1 was prepared in water and the $\mathrm{pH}$ titration for the probe was conducted in aqueous solution containing $20 \mathrm{mM}$ TrisHCl pH 7.4. A $5 \mathrm{M} \mathrm{NaOH}$ solution or $12 \mathrm{M} \mathrm{HCl}$ solution was used for $\mathrm{pH}$ adjustment. All the samples were mixed by using a micropipet and then taken for absorbance and emission measurements in a quartz optical cell of $1 \mathrm{~cm}$ optical path length.

Fluorescence Quantum Yield Measurement. The stock solutions of $\mathrm{F}(\mathrm{COOH})_{2}$ and FSM/DNA probe 1 were prepared in DMSO and water, respectively. The solutions were then diluted in $2 \mathrm{~mL}$ of water with different $\mathrm{pH}$ values to the desired final concentration for the fluorescence quantum yield $\left(\Phi_{\mathrm{f}}\right)$ measurement. Fluorescein $\left(\Phi_{\mathrm{f}}=0.92\right)$ was used as a reference for comparison.

Cell Incubation and Cytotoxicity Investigation. Normal human liver HL-7702 cell line was used for the evaluation of the cytotoxicity of FSM/DNA probe. FSM/DNA probe 1 was directly dissolved in ultrapure water. In all the experiments, HL7702 cells were maintained in a DMEM (Gibco invitrogen) medium consisting of $10 \%$ fetal bovine serum (FBS). With respect to cytotoxicity testing by MTT method, the cells were seeded in 96-well culture plates at a density of $5 \times 10^{4}$ cells/ well and incubated for $24 \mathrm{~h}$ at $37{ }^{\circ} \mathrm{C}$ with $5 \% \mathrm{CO}_{2}$. After removal of the medium, cells were washed three times with phosphate buffered saline (PBS, $\mathrm{pH}$ 7.4) and treated with various doses of FSM/DNA probe 1 in fresh medium and incubated for an additional $72 \mathrm{~h}$ at $37{ }^{\circ} \mathrm{C}$ with $5 \% \mathrm{CO}_{2}$. At the end of the incubation period, $20 \mu \mathrm{L}$ of MTT $(5 \mathrm{mg} / \mathrm{mL})$ was added per well and the plates were incubated for $4 \mathrm{~h}$ at $37^{\circ} \mathrm{C}$. The supernatant was removed and $150 \mu \mathrm{L}$ of DMSO per well was added to dissolve the produced formazan. After shaking the plates for $10 \mathrm{~min}$, absorbance values of the wells were recorded with the ELX 800 Universal Microplate Reader (Bio-Tek Instruments, Inc., Winooski, VT, U.S.A.) at $490 \mathrm{~nm}$. Blank control group (only HL-7702 cells) and paclitaxel (PTX) treated positive control group were also performed. The cell viability rate (VR) was calculated according to the following equation:

$$
\mathrm{VR}=A / A_{0} \times 100 \%
$$

where $A$ is the absorbance of the experimental group and $A_{0}$ is the absorbance of the negative control group. Besides, in order to approve the validity of the method, the MTT analysis of 10 $\mu \mathrm{g} / \mathrm{mL}$ PTX for $72 \mathrm{~h}$ was also conducted, and the cell survival percentage is calculated to be $13.2 \pm 0.4 \%$.

Cell Imaging Study with the FSM/DNA Probe 1. HL7702 cells maintained in a DMEM medium consisting of $10 \%$ FBS were incubated on glass slides in 6-well cell culture plates and cultured at $37{ }^{\circ} \mathrm{C}$ under $5 \% \mathrm{CO}_{2}$ for $24 \mathrm{~h}$. After removal of the medium, HL-7702 cells were washed three times with PBS ( $\mathrm{pH}$ 7.4) and treated with $1 \mu \mathrm{M}$ FSM/DNA probe 1 for $15 \mathrm{~min}$ in $20 \mathrm{mM}$ HEPES buffer with different $\mathrm{pH}$ values at room temperature. After that, the culture medium was discarded and 
the cells were rinsed twice in PBS. Then, the glass slides were taken out and the microscopic images were acquired with an Olympus FluoView FV1000 confocal microscope. The excitation wavelength of laser light is $340 \mathrm{~nm}$. Another plate of HL-7702 cells as a control was treated in the same way except for the addition of FSM/DNA probe 1 .

\section{RESULTS AND DISCUSSION}

Sequence Design for FSM/DNA Probes. In our previous work, we have set up logic gates capable of NOT, INH, and AND logic operations based on FSM/DNA probes via singleand two-step FRET process and the sequence-recognition mechanism of DNA. ${ }^{47}$ In this study, 2,7-bis(4-phenylcarboxylic acid)-fluorene derivative $\mathrm{F}(\mathrm{COOH})_{2}$ was linked with welldesigned, single-stranded DNA (ssDNA) including random DNA, split $\mathrm{K}^{+}$specific DNA, and ATP aptamer to form the FSM/DNA probes, which can be exploited to implement multiple-input or multiple-output logic functions.

Implementation of the Multiple Logic Functions with FSM/DNA Probes. As shown in Figure 1a, probe 1 was a random ssDNA modified with the fluorophore FSM at its $5^{\prime}$ end and it gave a high fluorescence emission at $412 \mathrm{~nm}$ by excitation at wavelength of $340 \mathrm{~nm}$. In the presence of the complementary DNA (DNAc, $I_{1}$ ), double-stranded DNA (dsDNA) was formed and the fluorescence intensity of FSM was sharply reduced. The fluorescence quenching of the FSMmodified probe by dsDNA was due to the photoinduced electron transfer (PET) mechanism, which usually occurs between organic fluorophores and suitable electron donating moieties, ${ }^{57}$ such as the nucleobase guanine $(G)$ used in our experiments. As a result, when the complementary DNA containing $G$ bases was added to the solution of FSM/DNA probe 1 to form FSM/dsDNA, the enhanced density of G bases effectively quenched the fluorescence of the FSM moiety. The result of fluorescence quenching upon hybridization was consistent with that reported in the literature. ${ }^{38}$ More interesting, we found that the fluorescence of FSM-modified probe 1 can be quenched by SG I $\left(\mathrm{I}_{2}\right)$ due to the overlap of the fluorescence spectra of FSM/DNA probe and the absorption spectra of SG I (Figure S1). However, in the presence of both DNAc and SG I, the SG I preferentially intercalated into the dsDNA and the distance between SG I and FSM was shortened. Hence, this caused the effective FRET from the FSM to SG I, resulting the high fluorescence emission of SG I at $526 \mathrm{~nm}$. Therefore, the integrated dual-input and dualoutput NOR and AND logic gates operating in parallel were realized by monitoring the changes in fluorescence intensity at 412 and $526 \mathrm{~nm}$, respectively (Figure 1b,c). In this logic system, single-step FRET combined with the sequencerecognition mechanism of DNA forms the basis of the construction of the integrated NOR and AND logic gates.

To investigate the effect of the formation of G-quadruplex on the fluorescence properties of FSM/DNA probes, $\mathrm{K}^{+}$stabilized G-quadruplex DNA was split into two fragments. As shown in Figure 2a, FSM-modified $5^{\prime}$ fragment of split $\mathrm{K}^{+}$specific DNA and its $3^{\prime}$ fragment (named probe 2 and S1, respectively, in Scheme 1) were used as the gate strands. In the absence of $\mathrm{K}^{+}$ $\left(I_{1}\right)$, probe 2 and $S 1$ were dissociated in the solution and the interaction between the gate strands and SG I was weak. Therefore, the FRET from FSM to SG I was inefficient. If the $\mathrm{K}^{+}$was present, the gate strands bond with $\mathrm{K}^{+}$to form the Gquadruplex. Contrary to the quenching effect upon hybridization, the emission of FSM was just slightly decreased

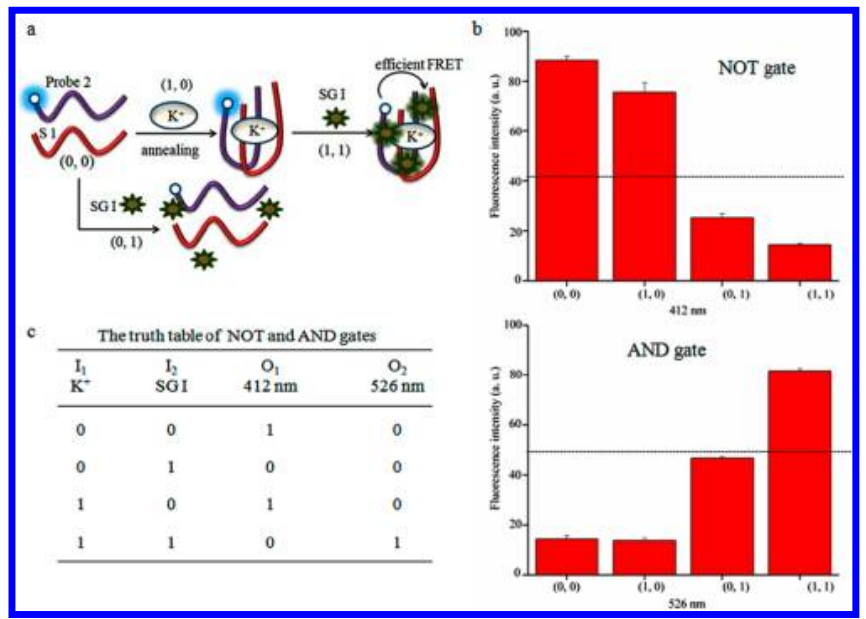

Figure 2. Integrated NOT and AND logic gates based on probe 2. (a) Schematic representation of the performing of NOT and AND gates: $\mathrm{I}_{1}, \mathrm{~K}^{+} ; \mathrm{I}_{2}$, SG I. (b) Fluorescence changes at 412 and $526 \mathrm{~nm}$ by excitation at $380 \mathrm{~nm}$. (c) Truth table of the NOT and AND gates.

compared with the initial state because the guanine $(G)$ base could be a quencher for fluorene connected to oligonucleotides. ${ }^{38,58}$ When the SG I $\left(\mathrm{I}_{2}\right)$ was added into the solution containing probe 2 and $S 1$, the fluorescence intensity of FSM was quenched by SG I. Only $\mathrm{K}^{+}$and SG I are present at the same time, probe 2 and $S 1$ formed into the G-quadruplex structure and SG I was intercalated into the G-quadruplex, inducing the efficient FRET from FSM to SG I. Thus, there was a decrease of fluorescent signal at $412 \mathrm{~nm}$ and an enhancement at $526 \mathrm{~nm}$. The integrated dual-input and dual-output NOT and AND logic gates operating in parallel were realized by monitoring the fluctuation of fluorescence intensities at 412 and $526 \mathrm{~nm}$, respectively (Figure $2 \mathrm{~b}, \mathrm{c}$ ).

As described above, the fluorescence intensity of FSM/DNA probe can be quenched by SG I. Here, we found that its fluorescence can also be quenched by the EB molecule (Figure S1) and aptamer-target complex. The sequence of probe 3 consisted of ATP aptamer was used as gate strand for the construction of the three-input NOR gate. In the presence of ATP, probe 3 folded up into a unique three-dimensional structure in order to strongly bond to ATP and form the ATPaptamer complex. Interestingly, the fluorescence of FSM was quenched by the formation of the aptamer-target complex, which could be derived from the PET process and the local structural alteration that influences the fluorene interactions with the nearby bases upon binding to the ligand. The formation of ternary structure of aptamer-ligand complex made the FSM fluorophore close to the G bases, resulting in a stronger interaction and more efficient electron transfer between FSM labeling and nearby bases. Therefore, the presence of any one of the three molecules (ATP, SG I, and EB) can result in the quenching of the probe 3 by excitation at $340 \mathrm{~nm}$ (Figure 3). This was consistent with the truth table of the three-input NOR gate. More importantly, the aptamertarget complex induced quenching of probe 3 was utilized for the detection of ATP with a limit of detection (LOD) of 0.1 $\mathrm{mM}$ (Figure $4 \mathrm{a}$ and its inset). Figure $4 \mathrm{~b}$ shows the selectivity of this quencher-free sensory system against ATP and its analogues (AMP, CTP, GTP, and UTP). Prominent fluorescence quenching was observed only in the presence of ATP molecule due to the specific binding affinity between ATP 


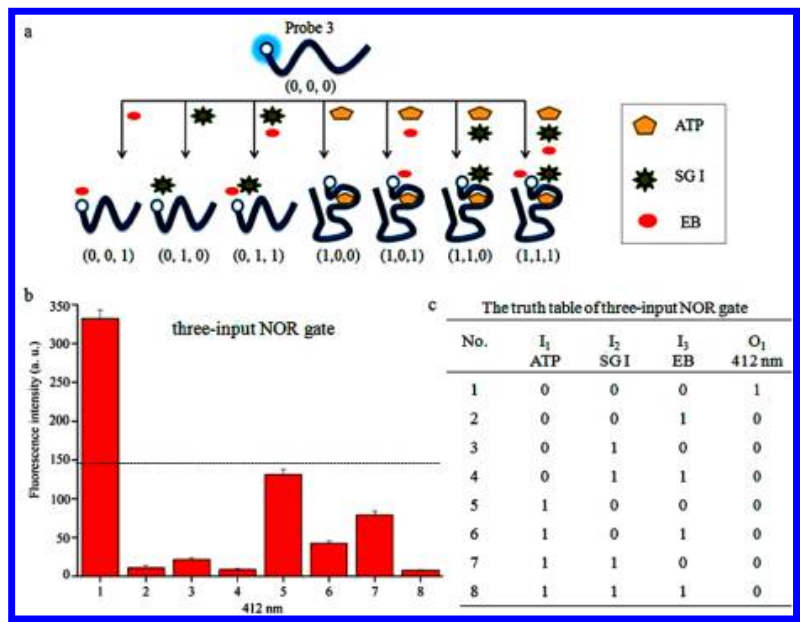

Figure 3. Three-input NOR logic gate based on probe 3. (a) Schematic representation of the performing of three-input NOR gate: $\mathrm{I}_{1}$, ATP; $\mathrm{I}_{2}, \mathrm{SG} \mathrm{I} \mathrm{I}_{3}, \mathrm{~EB}$. (b) Fluorescence changes at $412 \mathrm{~nm}$ by excitation at $340 \mathrm{~nm}$. (c) Truth table of the three-input NOR gate.

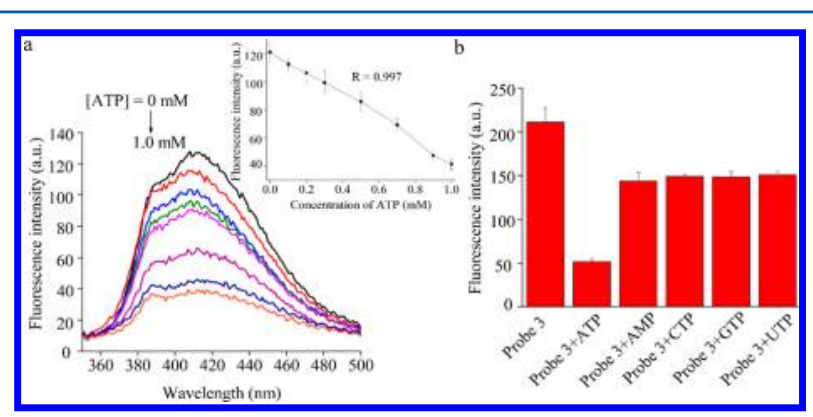

Figure 4. Fluorescence turn-off detection of ATP based on probe 3 . (a) Fluorescence spectra of probe 3 as a function of $[\mathrm{ATP}]: 0,0.1,0.2$, $0.3,0.5,0.7,0.9$, and $1.0 \mathrm{mM}$. Inset: The resulting calibration curve. (b) Selectivity of probe 3 based sensory system against ATP and ATP analogues, respectively. Fluorescence intensities were recorded at 412 $\mathrm{nm}$ by excitation at $340 \mathrm{~nm}$ : [probe 3] $=2 \times 10^{-8} \mathrm{M}$ in $10 \mathrm{mM}$ Tris $\mathrm{HCl}$ buffer $\mathrm{pH} 7.4$ containing $100 \mathrm{mM} \mathrm{NaCl}$ and $50 \mathrm{mM} \mathrm{MgCl}_{2}$; [ATP and analogues] $=1.0 \mathrm{mM}$. Standard deviation errors from three independent experiments are shown (bars).

and probe 3, showing excellent selectivity against other ATP analogues.

Optical Properties of $\mathrm{F}(\mathrm{COOH})_{2}$ under Different $\mathrm{pH}$ Conditions. The absorption and emission spectra changed with $\mathrm{pH}$ were evaluated with 2,7-bis(4-phenylcarboxylic acid)fluorene derivative $\left(\mathrm{F}(\mathrm{COOH})_{2}\right)$. As shown in Figure $5 \mathrm{a}$, the $\mathrm{UV}$-vis absorbance peaks of $\mathrm{F}(\mathrm{COOH})_{2}$ displayed at $340 \mathrm{~nm}$ at neutral and alkaline $\mathrm{pH}$ ranges (7-14). With decreasing $\mathrm{pH}$, the absorption maximum was red-shifted to $350 \mathrm{~nm}$ at acidic $\mathrm{pH}$ ranges $(1-6)$. It could be due to the fact that the carboxylcontaining $\mathrm{F}(\mathrm{COOH})_{2}$ molecules were more prone to aggregation in the acidic conditions than that in the neutral and alkaline conditions (existed in the carboxylated form of $\left.\mathrm{F}\left(\mathrm{COO}^{-}\right)_{2}\right)$, which resulted in the decrease of the energy for $\pi-\pi$ transitions and red shift in absorption spectra. With respect to the emission spectra (Figure $5 \mathrm{~b}), \mathrm{F}(\mathrm{COOH})_{2}$ compound showed strong fluorescence intensities ("ON" state) at $404 \mathrm{~nm}$ in neutral and alkaline solutions, which was ascribed to the deprotonation process occurring at the $-\mathrm{COOH}$ groups and thus the formation of carboxylate anion $\left(\mathrm{F}\left(\mathrm{COO}^{-}\right)_{2}\right)$. In contrast, when a certain amount of $\mathrm{HCl}$ solution was added to the $\mathrm{F}\left(\mathrm{COO}^{-}\right)_{2}$ solution, the fluorescence

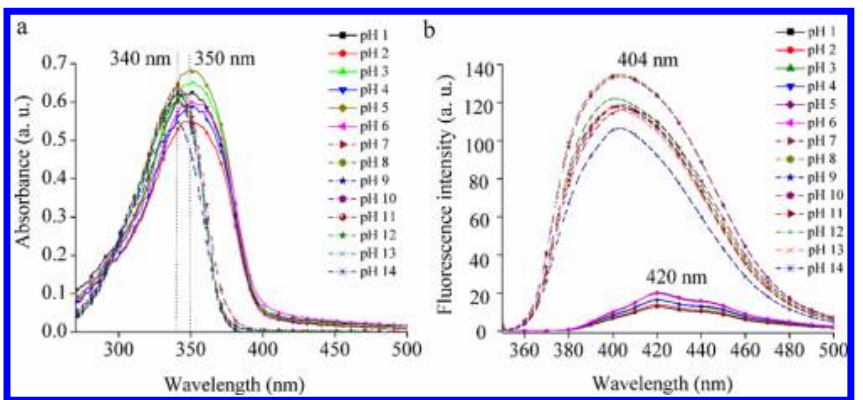

Figure 5. Optical spectra of $\mathrm{F}(\mathrm{COOH})_{2}$ under different $\mathrm{pH}$ conditions. (a) UV-vis absorption spectra of $\mathrm{F}(\mathrm{COOH})_{2}(1.7 \times$ $\left.10^{-5} \mathrm{M}\right)$ and $(\mathrm{b})$ fluorescence spectra of $\mathrm{F}(\mathrm{COOH})_{2}\left(3.4 \times 10^{-7} \mathrm{M}\right)$ at various $\mathrm{pH}$ values in aqueous solvents $\left(\mathrm{H}_{2} \mathrm{O} / \mathrm{DMSO}=5000: 1\right)$ by excitation at $340 \mathrm{~nm}$.

quenching effects ("OFF" state) can be observed and the peaks were red-shifted to $420 \mathrm{~nm}$ as the result of the formation of protonated $\mathrm{F}(\mathrm{COOH})_{2}$ at acidic $\mathrm{pH}$ values. Therefore, the solution of $\mathrm{F}(\mathrm{COOH})_{2}$ was found to be sensitive to $\mathrm{pH}$ values in terms of the absorption and emission properties and it could be correlated with the protonation/deprotonation processes. Considering all the results, the reasons for the changes of optical intensities with $\mathrm{pH}$ values can be concluded as follows: (i) the intermolecular force between protonated $\mathrm{F}(\mathrm{COOH})_{2}$ molecules was enhanced and they were aggregated in the acidic conditions, resulting in a red shift of the absorption band; (ii) strong-coupling of excitons can be obtained from the aggregated $\mathrm{F}(\mathrm{COOH})_{2}$ molecules, leading to the nonradiation energy transfer and the quenching of fluorescence of $\mathrm{F}(\mathrm{COOH})_{2}$; (iii) the electrostatic repulsion between carboxylate anions kept the molecules apart and the fluorescence was recovered after the deprotonation of the $\mathrm{F}(\mathrm{COOH})_{2}$ at neutral and alkaline conditions.

pH-Triggered Molecular Switch. As expected, the $\mathrm{F}(\mathrm{COOH})_{2}$ exhibited reversible optical property depending on protonation/deprotonation processes, which was demonstrated by the $\mathrm{pH}$ titration upon adding different amounts of standard $\mathrm{NaOH}$ or $\mathrm{HCl}$ solution (Figure S2). Thus, a fluorescent molecular switch can be obtained through a $\mathrm{pH}$ adjustment protocol. As shown in Figure 6a, the solution of $\mathrm{F}(\mathrm{COOH})_{2}$ shows strong fluorescence intensity at $\mathrm{pH} 8\left(\Phi_{\mathrm{f}}=\right.$ $64 \%)$ and weak intensity at $\mathrm{pH} 4\left(\Phi_{\mathrm{f}}=8 \%\right)$. The fluorescence intensities were cycled between high ("ON" state) and low ("OFF" state) levels by the alternative addition of $\mathrm{HCl}$ and

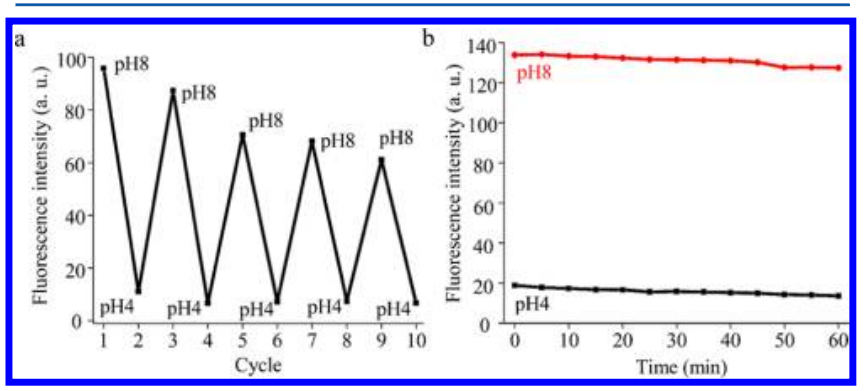

Figure 6. (a) Reversible operations of the molecular switch with $\mathrm{F}(\mathrm{COOH})_{2}$ upon alternative adjustment of the solution to $\mathrm{pH} 8$ and $\mathrm{pH}$ 4. (b) Fluorescence intensities changed over time. The emission was determined at $404 \mathrm{~nm}$ for $\mathrm{pH} 8$ and $420 \mathrm{~nm}$ for $\mathrm{pH} 4$ by excitation at $340 \mathrm{~nm}$. $\left[\mathrm{F}(\mathrm{COOH})_{2}\right]=3.4 \times 10^{-7} \mathrm{M}$ in aqueous solvents $\left(\mathrm{H}_{2} \mathrm{O} /\right.$ DMSO $=5000: 1)$. 


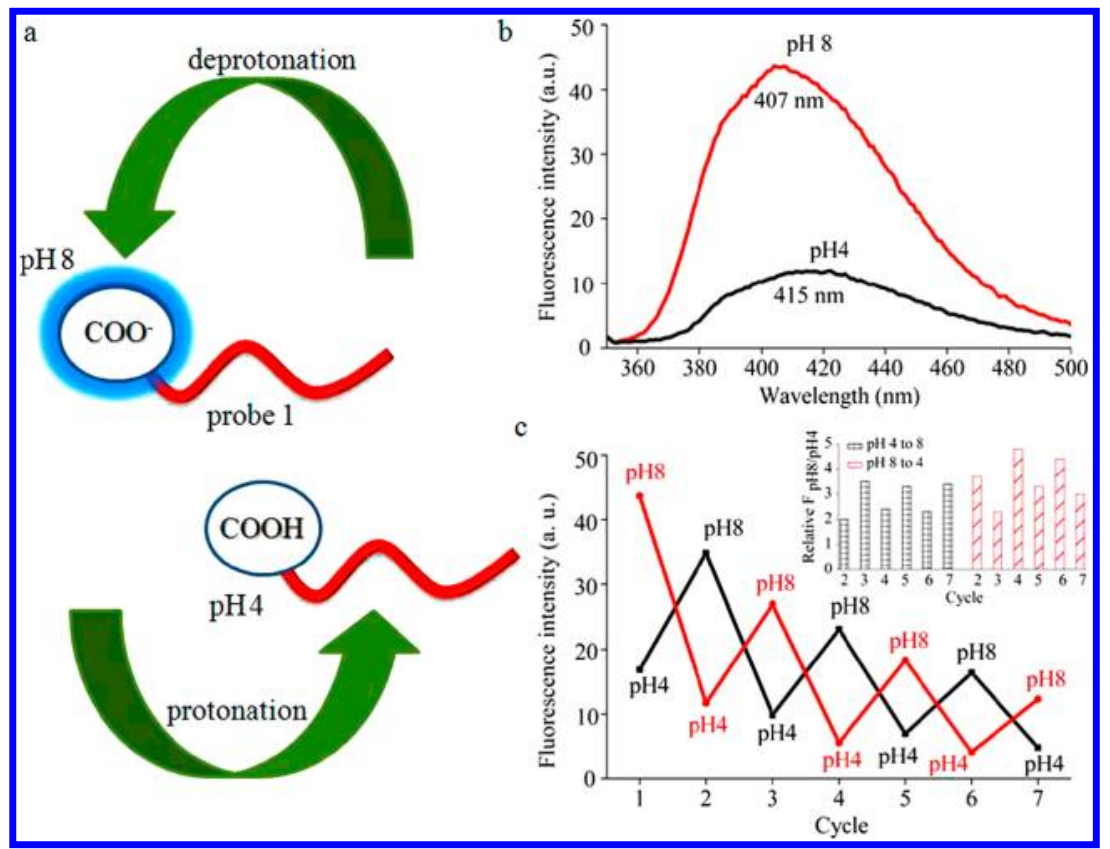

Figure 7. (a) Schematic representation of $\mathrm{pH}$-triggered molecular switch with probe 1 via the reversible protonation/deprotonation processes. (b) Fluorescence spectra of probe 1 at $\mathrm{pH} 4$ and 8 . (c) Fluorescence intensities of the probe 1 switched with $\mathrm{pH}$ values. The intensities were determined at $407 \mathrm{~nm}$ for $\mathrm{pH} 8$ and $415 \mathrm{~nm}$ for $\mathrm{pH}$ 4. Inset: The increase or decrease in fluorescence intensities for each cycle; [probe 1 ] $=2 \times 10^{-8} \mathrm{M}$ in aqueous buffer containing $20 \mathrm{mM}$ TrisHCl pH 7.4; excited at $340 \mathrm{~nm}$.

$\mathrm{NaOH}$ solutions. However, it should be noted that a gradual decrease in fluorescence intensities occurred as a result of the concentration dilution of the system upon changing the $\mathrm{pH}$ values. Furthermore, the $\mathrm{pH}$-induced switch system showed at least 7-fold increase or decrease in fluorescence intensity within $1 \mathrm{~h}$ (Figure 6b). However, the fluorene derivative FS with two active esters was used as control sample to evaluate the effect of $\mathrm{pH}$ values on fluorescence. Upon the addition of $\mathrm{HCl}$ or $\mathrm{NaOH}$ to the solution of FS, there were no obvious changes in their emission spectra (Figure S3). The absence of a $\mathrm{pH}$-dependent fluorescence "ON-OFF" switch in the case of FS indirectly confirmed the switching mechanism of the carboxylic acid substituted fluorene derivative $\left(\mathrm{F}(\mathrm{COOH})_{2}\right)$.

As described above, the solution of $\mathrm{F}(\mathrm{COOH})_{2}$ showed $\mathrm{pH}$ responsive switching function. However, $\mathrm{F}(\mathrm{COOH})_{2}$ was dissolved in organic solvent (DMSO or DMF), which limited the utility in biological applications. The FSM/DNA probe was completely water-soluble and could be suitable for biological applications. Since the $\mathrm{F}(\mathrm{COOH})_{2}$ compound has two carboxylic acid functional groups, it remains an active one $(-\mathrm{COOH})$ in FSM/DNA probe when the ssDNA was covalently bonded with one carboxyl terminus of $\mathrm{F}(\mathrm{COOH})_{2}$. Hence, the $\mathrm{pH}$-triggered reversible fluorescence molecular switch can be developed with the FSM/DNA probe 1 in totally aqueous solution, and the working principle was described in Figure 7a. The emission of probe 1 at $407 \mathrm{~nm}(\mathrm{pH} \mathrm{8)}$ was strong due to the deprotonated form of probe 1 . Under acidic conditions ( $\mathrm{pH} 4)$, a pronounced fluorescence quenching was observed, and the peak position was red-shifted to $415 \mathrm{~nm}$, which was the result of the formation of protonated probe 1 (Figure 7b). Thus, by the cyclic treatment of the probe 1 with $\mathrm{NaOH}$ and $\mathrm{HCl}$ solutions, the emission intensity was switched "ON" or "OFF" between the deprotonated and protonated forms of the probe 1 (Figure 7c). Although the fluorescence intensity of probe 1 was not fully restored and gradually decreased with the $\mathrm{pH}$-cycling of the system due to a conventional dilution effect and a photobleaching of the fluorescence label of FSM, the fluorescence intensities between the "ON" and "OFF" states fluctuated more than 2-fold (inset of Figure $7 \mathrm{c}$ ), which indicated that an actual switching function was realized.

Living Cell Imaging. The applicability of FSM/DNA probe for live cell imaging was conducted by virtue of a confocal laser scanning microscope. Normal human liver cells HL-7702 showed negligible background fluorescence (data not shown). However, after incubation with $1 \mu \mathrm{M}$ probe 1 in HEPES buffer with different $\mathrm{pH}$ values for $15 \mathrm{~min}$ at room temperature, the cells showed strong blue fluorescence staining at $\mathrm{pH} 8$ (Figure $8 \mathrm{~d}, \mathrm{f})$. While the obvious fluorescence quenching was observed

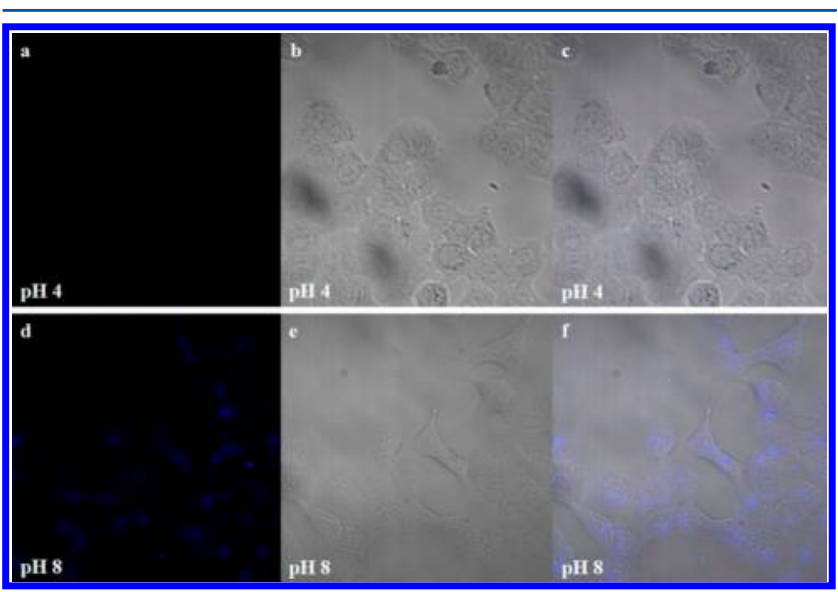

Figure 8. Fluorescence (a, d) and bright-field images (b, e) of living HL-7702 cells incubated with $1 \mu \mathrm{M}$ FSM/DNA probe 1 in HEPES buffer with $\mathrm{pH} 4$ (top) or $\mathrm{pH} 8$ (bottom) for $15 \mathrm{~min}$ at room temperature. Overlays of fluorescence and brightfield images were shown in (c) and (f) for $\mathrm{pH} 4$ or 8 , respectively. All images were taken at a magnification $400 \times$; excited at $340 \mathrm{~nm}$. 
for $\mathrm{pH} 4$ (Figure 8a,c), indicating the fluorescence "ON-OFF" switching capability of the probe 1 in live cell imaging. Additionally, bright-field images taken after the probe treatment indicated that the cells were viable throughout the imaging experiments (Figure 8b,e). Overlays of fluorescence and brightfield images further demonstrated that the fluorescence staining was evident in the cytoplasm at extracellular buffer solution of pH 8 (Figure $8 \mathrm{f}$ ), suggesting that the FSM/DNA probe was cell-permeable.

Generally, the cytotoxic and cell-permeable characteristics of fluorescent materials are important to their application as bioprobes. Hence, the HL-7702 cells treated with different concentrations of FSM/DNA probe 1 were used for the determination of the cytotoxic effects by MTT assay. After the incubation with a FSM/DNA probe 1 for $72 \mathrm{~h}$, the probe 1 was found to be nontoxic to HL-7702 cells (Figure 9). It showed a

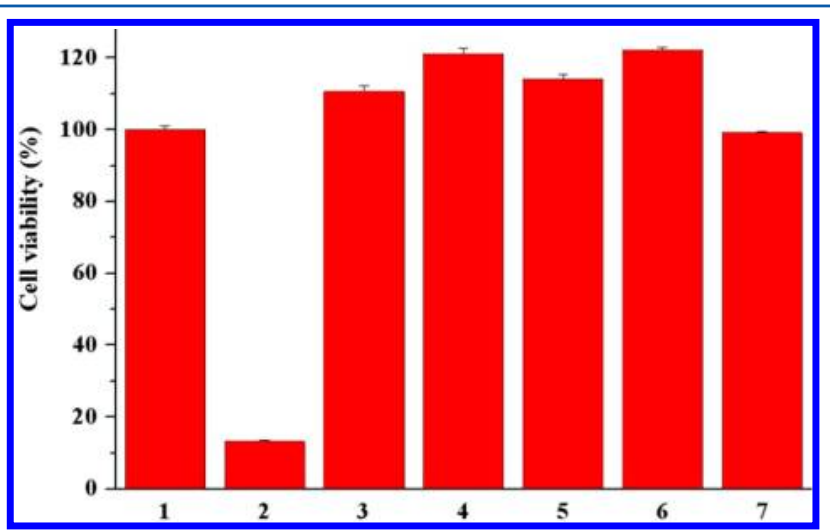

Figure 9. Cytoxic effects of the FSM/DNA probe 1 against HL-7702 cells upon $72 \mathrm{~h}$ of incubation. 1: Blank control, namely, HL-7702 cells; 2: HL-7702 cells treated with $10 \mu \mathrm{g} / \mathrm{mL}$ PTX as positive control; 3-7: HL-7702 cells treated with different concentrations $(1.56,3.12,6.25$, 12.5 , and $25 \mu \mathrm{g} / \mathrm{mL}$ ) of FSM/DNA probe 1 . Standard deviation errors from three independent experiments were shown (bars).

cell viability of over $99 \%$ even at the high concentration of 25 $\mu \mathrm{g} / \mathrm{mL}$. In addition, the viability values of more than $100 \%$ indicated the ability to promote cell proliferation at a range of concentrations from 1.56 to $12.5 \mu \mathrm{g} / \mathrm{mL}$. These data suggested that the FSM/DNA probe had no cytotoxicity and could reasonably be used for intracellular investigation.

\section{CONCLUSIONS}

In this article, we demonstrated multiple logic gates including the dual-input dual-output NOR and AND gates, dual-input dual-output NOT and AND gates, and a three-input NOR gate based on the FSM/DNA probes, which sequences were welldesigned. The combination of the optical properties of FSM, SG I, and EB molecules and the recognition capability of DNA forms the basis for the design. As well as we know, various DNA intercalating chromophores such as SG I, EB, PicoGreen (PG), TOTO, and YOYO have been exploited for the construction of FRET-based DNA logic gates, which can be used as donor or acceptor molecules. However, in this work, the molecules of SG I and EB can function as a quencher since they absorbed the emission of FSM without giving a strong fluorescent signal. These results indicated that the optical property of the FSM-modified DNA was quite different from those of commonly used fluorescein (or their derivatives) labeled DNA. Especially for the logic gates and biosensors based on the DNA conformational changes, one of the most popular approaches is to use dual-labeled DNA probes containing a $5^{\prime}$ fluorophore and a $3^{\prime}$ quencher at each end of DNA (such as molecular beacon) to tune the single- or twostep FRET process. The fluorescence intensity of the FSM/ DNA probe can be quenched by dsDNA, aptamer-target complex or free dyes (such as SG I and EB) without the attachment of additional quencher moiety. The quencher-free FSM/DNA probe also showed the ability for detection of ATP with a LOD of $1.0 \mathrm{mM}$. Although the sensitivity of this method is relatively low, it has the obvious advantage of reducing the cost of DNA modification. In addition, the $3^{\prime}$ end of FSM/ DNA probe and the alkyl chains of the fluorene moiety could be used for immobilization to attach the probe to the surface of electrode or chip-based format, and the combination of different techniques might be able to increase the sensitivity and improve the detection limit of the FSM/DNA probe based sensory system. Meanwhile, a new $\mathrm{pH}$-induced fluorescence "ON-OFF" switch was developed with the carboxylic acid terminated fluorene derivatives $\mathrm{F}(\mathrm{COOH})_{2}$ and FSM/DNA probe by taking advantage of the reversible optical properties depending on protonation/deprotonation processes. The $\mathrm{F}(\mathrm{COOH})_{2}$ in the deprotonated form emitted strong fluorescence at neutral and alkaline $\mathrm{pH}$ ranges and an obvious quenching effects were observed at acidic $\mathrm{pH}$ ranges which was attributed to the protonation of $\mathrm{F}\left(\mathrm{COO}^{-}\right)_{2}$. The "quenching and recovery" of the fluorescence intensities were obtained by changing the $\mathrm{pH}$ values of the $\mathrm{F}(\mathrm{COOH})_{2}$ solution from acidic to alkaline conditions. Additionally, the "ON-OFF" switching function with FSM/DNA probe was conducted in $100 \%$ aqueous solution. The low cytotoxicity, cell membrane permeability, as well as the exclusive blue fluorescence staining in cytoplasm at $\mathrm{pH} 8$, was observed for the FSM/DNA probe. The sequence and terminal functional group (such as carboxylic acid (COOH) group) of the FSM/DNA probe can be conveniently and easily designed and modified, making it promising candidate for optical tracking and fluorescence bioimaging.

\section{ASSOCIATED CONTENT}

\section{Supporting Information}

Normalized absorption spectra of SG I, EB, and fluorescence spectra of FSM/DNA probe 1. Fluorescence spectra data of $\mathrm{F}(\mathrm{COOH})_{2}$ and $\mathrm{FS}$ at different $\mathrm{pH}$ values. This material is available free of charge via the Internet at http://pubs.acs.org.

\section{AUTHOR INFORMATION}

\section{Corresponding Author}

*E-mail: yangrq@qibebt.ac.cn.

\section{Notes}

The authors declare no competing financial interest.

\section{ACKNOWLEDGMENTS}

This work was supported by the Samsung Global Research Outreach (GRO) Program, the Ministry of Science and Technology of China (2010DFA52310), and the National Natural Science Foundation of China (21274161, 51173199).

\section{REFERENCES}

(1) de Silva, A. P.; Gunaratne, H. Q. N.; McCoy, C. P. A Molecular Photoionic AND Gate Based on Fluorescent Signalling. Nature 1993, $364,42-44$. 
(2) Liu, Y.; Tang, Y.; Cao, A. Reversible Logic Gate Modulated by Nucleases Based on Cationic Conjugated Polymer/DNA Assembly. Polym. Chem. 2013, 4, 5206-5211.

(3) Kim, K. W.; Kim, Y. E.; Bocharova, V.; Halamek, J.; Lee, C. W.; Katz, E.; Oh, M. K. Logic Circuit Upon Angiogenic Response Controlled by Enzyme-Linked Iron Oxide Microparticles-Towards Biocomputing in Human Cells. Chem. Commun. 2012, 48, 6918-6920.

(4) Wang, Y.; Xin, B.; Duan, X.; Xing, G.; Wang, S. Assembly of Anionic Conjugated Polymer with 6-O-Modified PNP- $\beta$-Galactoside for Fluorescence Logic-Signal-Based Multiplex Detections of Enzymes. Macromol. Rapid Commun. 2010, 31, 1473-1478.

(5) Ashkenasy, G.; Ghadiri, M. R. Boolean Logic Functions of a Synthetic Peptide Network. J. Am. Chem. Soc. 2004, 126, 1114011141.

(6) Carell, T. Molecular Computing: DNA as a Logic Operator. Nature 2011, 469, 45-46.

(7) Fan, C.; Plaxco, K. W.; Heeger, A. J. Biosensors Based on Binding-Modulated Donor-Acceptor Distances. Trends Biotechnol. 2005, 23, 186-192.

(8) Kim, B.; Jung, I. H.; Kang, M.; Shim, H. K.; Woo, H. Y. Cationic Conjugated Polyelectrolytes-Triggered Conformational Change of Molecular Beacon Aptamer for Highly Sensitive and Selective Potassium Ion Detection. J. Am. Chem. Soc. 2012, 134, 3133-3138.

(9) Lin, Y.; Tao, Y.; Pu, F.; Ren, J.; Qu, X. Combination of Graphene Oxide and Thiol-Activated DNA Metallization for Sensitive Fluorescence Turn-On Detection of Cysteine and Their Use for Logic Gate Operations. Adv. Funct. Mater. 2011, 21, 4565-4572.

(10) Zhuang, J.; Lai, W.; Chen, G.; Tang, D. A. Rolling Circle Amplification-Based DNA Machine for miRNA Screening Coupling Catalytic Hairpin Assembly with DNAzyme formation. Chem. Commun. 2014, 50, 2935-2938.

(11) Bi, S.; Cui, Y.; Dong, Y.; Zhang, N. Target-Induced Selfassembly of DNA Nanomachine on Magnetic Particle for MultiAmplified Biosensing of Nucleic Acid, Protein, and Cancer Cell. Biosens. Bioelectron. 2014, 53, 207-213.

(12) Li, W.; Yang, Y.; Yan, H.; Liu, Y. Three-Input Majority Logic Gate and Multiple Input Logic Circuit Based on DNA Strand Displacement. Nano Lett. 2013, 13, 2980-2988.

(13) Ma, D. L.; He, H. Z.; Chan, D. S. H.; Leung, C. H. Simple DNA-Based Logic Gates Responding to Biomolecules and Metal Ions. Chem. Sci. 2013, 4, 3366-3380.

(14) Lake, A.; Shang, S.; Kolpashchikov, D. M. Molecular Logic Gates Connected through DNA Four-Way Junctions. Angew. Chem., Int. Ed. 2010, 49, 4459-4462.

(15) Yang, J.; Shen, L.; Ma, J.; Schlaberg, H. I.; Liu, S.; Xu, J.; Zhang, C. Fluorescent Nanoparticle Beacon for Logic Gate Operation Regulated by Strand Displacement. ACS Appl. Mater. Interfaces 2013, 5, 5392-5396.

(16) Zhang, C.; Wu, L.; Yang, J.; Liu, S.; Xu, J. A Molecular Logical Switching Beacon Controlled by Thiolated DNA Signals. Chem. Commun. 2013, 49, 11308-11310.

(17) Feng, L.; Zhao, A.; Ren, J.; Qu, X. Lighting Up Left-Handed ZDNA: Photoluminescent Carbon Dots Induce DNA B to Z Transition and Perform DNA Logic Operations. Nucleic Acids Res. 2013, 41, 7987-7996.

(18) Zhang, L.; Zhang, Y.; Liang, R.; Qiu, J. Colorimetric Logic Gates Based on Ion-Dependent DNAzymes. J. Phys. Chem. C 2013, 117, 12352-12357.

(19) Kahan-Hanum, M.; Douek, Y.; Adar, R.; Shapiro, E. A Library of Programmable DNAzymes that Operate in a Cellular Environment. Sci. Rep. 2013, 3, 1535.

(20) Willner, I.; Shlyahovsky, B.; Zayats, M.; Willner, B. DNAzymes for Sensing, Nanobiotechnology, and Logic Gate Applications. Chem. Soc. Rev. 2008, 37, 1153-1165.

(21) Ren, J.; Wang, J.; Wang, J.; Wang, E. Colorimetric Enantiorecognition of Oligopeptide and Logic Gate Construction Based on DNA Aptamer-Ligand-Gold Nanoparticle Interactions. Chem.-Eur. J. 2013, 19, 479-483.
(22) Song, C.; Wang, Z. G.; Ding, B. Smart Nanomachines Based on DNA Self-Assembly. Small 2013, 9, 2382-2392.

(23) Stojanovic, M. N.; Stefanovic, D. A Deoxyribozyme-Based Molecular Automaton. Nat. Biotechnol. 2003, 21, 1069-1074.

(24) Lienert, F.; Torella, J. P.; Chen, J. H.; Norsworthy, M.; Richardson, R. R.; Silver, P. A. Two- and Three-Input TALE-Based AND Logic Computation in Embryonic Stem Cells. Nucleic Acids Res. 2013, 41, 9967-9975.

(25) Zhu, J.; Zhang, L.; Dong, S.; Wang, E. Four-Way JunctionDriven DNA Strand Displacement and Its Application in Building Majority Logic Circuit. ACS Nano 2013, 7, 10211-10217.

(26) Sun, M.; Niu, Q.; Yang, R.; Du, B.; Liu, R.; Yang, W.; Peng, J.; Cao, Y. Fluorene-Based Copolymers for Color-Stable Blue LightEmitting Diodes. Eur. Polym. J. 2007, 43, 1916-1922.

(27) Yang, R.; Wu, H.; Cao, Y.; Bazan, G. C. Control of Cationic Conjugated Polymer Performance in Light Emitting Diodes by Choice of Counterion. J. Am. Chem. Soc. 2006, 128, 14422-14423.

(28) Farinhas, J.; Ferreira, Q.; Di Paolo, R. E.; Alcácer, L.; Morgado, J.; Charas, A. Nanostructured Donor/Acceptor Interfaces in Photovoltaic Cells using Columnar-Grain Films of a Cross-Linked Poly(fluorene-alt-bithiophene). J. Mater. Chem. 2011, 21, 1251112519.

(29) Cha, H.; Kong, H.; Chung, D. S.; Yun, W. M.; An, T. K.; Hwang, J.; Kim, Y. H.; Shim, H. K.; Park, C. E. Thermally Stable Amorphous Polymeric Semiconductors Containing Fluorene and Thiophene for Use in Organic Photovoltaic Cells. Org. Electron. 2010, $11,1534-1542$

(30) Kuhlmann, J. C.; de Bruyn, P.; Bouwer, R. K. M.; Meetsma, A.; Blom, P. W. M.; Hummelen, J. C. Improving the Compatibility of Fullerene Acceptors with Fluorene-Containing Donor-Polymers in Organic Photovoltaic Devices. Chem. Commun. 2010, 46, 7232-7234.

(31) Shih, P. I.; Chien, C. H.; Wu, F. I.; Shu, C. F. A Novel FluoreneTriphenylamine Hybrid That is a Highly Efficient Host Material for Blue-, Green-, and Red-Light-Emitting Electrophosphorescent Devices. Adv. Funct. Mater. 2007, 17, 3514-3520.

(32) Mondal, E.; Hung, W. Y.; Chen, Y. H.; Cheng, M. H.; Wong, K. T. Molecular Topology Tuning of Bipolar Host Materials Composed of Fluorene-Bridged Benzimidazole and Carbazole for Highly Efficient Electrophosphorescence. Chem.-Eur. J. 2013, 19, 10563-10572.

(33) Lei, Y.; Ma, F.; Tian, Y.; Niu, Q.; Mi, H.; Nurulla, I.; Shi, W. Fluorene-Based Conjugated Polymer with Tethered Thymines: Click Postpolymerization Synthesis and Optical Response to Mercury(II). J. Appl. Polym. Sci. 2013, 129, 1763-1772.

(34) Ma, J. P.; Yu, Y.; Dong, Y. B. Fluorene-Based Cu(II)-MOF: A Visual Colorimetric Anion Sensor and Separator Based on an AnionExchange Approach. Chem. Commun. 2012, 48, 2946-2948.

(35) Senthilkumar, T.; Asha, S. K. Self-Assembly in Tailor-Made Polyfluorenes: Synergistic Effect of Porous Spherical Morphology and FRET for Visual Sensing of Bilirubin. Macromolecules 2013, 46, 21592171.

(36) Cai, M.; Daniel, S. L.; Lavigne, J. J. Conjugated Bis and Poly(Dioxaborole)s for Optical Sensing of Lewis Bases Based on Main-Chain Perturbations. Chem. Commun. 2013, 49, 6504-6506.

(37) Thomas, S. W.; Joly, G. D.; Swager, T. M. Chemical Sensors Based on Amplifying Fluorescent Conjugated Polymers. Chem. Rev. 2007, 107, 1339-1386.

(38) Ergen, E.; Weber, M.; Jacob, J.; Herrmann, A.; Müllen, K. Twin Probes as a Novel Tool for the Detection of Single-Nucleotide Polymorphisms. Chem.-Eur. J. 2006, 12, 3707-3713.

(39) Ryu, J. H.; Seo, Y. J.; Hwang, G. T.; Lee, J. Y.; Kim, B. H. Triad Base Pairs Containing Fluorene Unit for Quencher-Free SNP Typing. Tetrahedron 2007, 63, 3538-3547.

(40) Wang, Z.; Zheng, G.; Lu, P. 9-(Cycloheptatrienylidene)Fluorene Derivative: Remarkable Ratiometric $\mathrm{pH}$ Sensor and Computing Switch with NOR Logic Gate. Org. Lett. 2005, 7, 36693672 .

(41) Feng, X.; Duan, X.; Liu, L.; Feng, F.; Wang, S.; Li, Y.; Zhu, D. Fluorescence Logic-Signal-Based Multiplex Detection of Nucleases 
with the Assembly of a Cationic Conjugated Polymer and Branched DNA. Angew. Chem., Int. Ed. 2009, 48, 5316-5321.

(42) Nishimura, T.; Ogura, Y.; Tanida, J. Fluorescence Resonance Energy Transfer-Based Molecular Logic Circuit Using a DNA Scaffold. Appl. Phys. Lett. 2012, 101, 233703.

(43) Guo, J.; Yang, R. An OR Logic Gate Based on Two Molecular Beacons. Mol. BioSyst. 2012, 8, 927-930.

(44) Abbel, R.; Schenning, A. P. H. J.; Meijer, E. W. Fluorene-Based Materials and Their Supramolecular Properties. J. Polym. Sci., Part A: Polym. Chem. 2009, 47, 4215-4233.

(45) Han, Q.; Su, Q.; Tang, L.; Feng, J.; Lu, P.; Wang, Y. Electron Transfer and Aggregate Formation Coinduced Emission Enhancement of 9-Cycloheptatrienylidene Fluorenes in the Presence of Cupric Chloride. J. Phys. Chem. C 2010, 114, 18702-18711.

(46) Pu, K. Y.; Liu, B. Fluorescence Turn-On Responses of Anionic and Cationic Conjugated Polymers toward Proteins: Effect of Electrostatic and Hydrophobic Interactions. J. Phys. Chem. B 2010, 114, 3077-3084.

(47) Guo, J.; Wang, T.; Yang, R. Construction of Logic Gates with the Fluorene-Based Small Molecule/DNA Probes. Mol. BioSyst. 2012, 8, 2347-2350.

(48) Aoun, R.; Yassin, A.; Jamal, M. E.; Kanj, A.; Rault-Berthelot, J.; Poriel, C. Synthesis of a Fluoresceine-Derivatized Fluorene and Its Electrogenerated Copolymers with Fluorene: New pH Indicators. Synth. Met. 2008, 158, 790-795.

(49) Zheng, G.; Wang, Z.; Tang, L.; Lu, P.; Weber, W. P. Color Tunable, Ratiometric $\mathrm{pH}$ Sensor for High and Low $\mathrm{pH}$ Values Base on 9-(Cycloheptatrienylidene)Fluorene Derivatives. Sens. Actuators, B 2007, 122, 389-394.

(50) Hu, B.; Su, Q.; Lu, P.; Wang, Y. BODIPY Modified 9Cycloheptatrienylidene Fluorene Derivatives: Fluorescent "Turn-On" for Detecting $\mathrm{Cu}^{2+}$ with Acidity. Sens. Actuators, B 2012, 168, 310317.

(51) Wang, Z.; Xing, Y.; Shao, H.; Lu, P.; Weber, W. P. Synthesis and Characterization of 9-(Cycloheptatrienylidene)Fluorene Derivatives: Acid-Triggered "Switch On" of Fluorophores. Org. Lett. 2005, 7, 8790.

(52) Park, K. K.; Park, J. W.; Hamilton, A. D. Solvent and pH Effects on the Fluorescence of 7-(Dimethylamino)-2-fluorenesulfonate. J. Fluoresc. 2007, 17, 361-369.

(53) Fuller, A. A.; Holmes, C. A.; Seidl, F. J. A Fluorescent Peptoid pH-Sensor. Biopolymers 2013, 100, 380-386.

(54) Park, S. Y.; Lee, Y.; Bae, K. H.; Ahn, C. H.; Park, T. G. Temperature/pH-Sensitive Hydrogels Prepared from Pluronic Copolymers End-Capped with Carboxylic Acid Groups via an Oligolactide Spacer. Macromol. Rapid Commun. 2007, 28, 1172-1176.

(55) Weng, J.; Mei, Q.; Jiang, W.; Fan, Q.; Tong, B.; Ling, Q.; Huang, W. Effect of $\mathrm{pH}$ on the Photophysical Properties of Two New Carboxylic-Substituted Iridium(III) Complexes. Analyst 2013, 138, 1689-1699.

(56) Sadhu, K. K.; Mizukami, S.; Yoshimura, A.; Kikuchi, K. pH Induced Dual "OFF-ON-OFF" Switch: Influence of a Suitably Placed Carboxylic Acid. Org. Biomol. Chem. 2013, 11, 563-568.

(57) Doose, S.; Neuweiler, H.; Sauer, M. Fluorescence Quenching by Photoinduced Electron Transfer: A Reporter for Conformational Dynamics of Macromolecules. ChemPhysChem 2009, 10, 1389-1398.

(58) Yang, X.; Zhu, Y.; Liu, P.; He, L.; Li, Q.; Wang, Q.; Wang, K.; Huang, J.; Liu, J. G-Quadruplex Fluorescence Quenching Ability: A Simple and Efficient Strategy to Design a Single-Labeled DNA Probe. Anal. Methods 2012, 4, 895-897. 